\title{
Monetary Policy and Financial Stability: A CEMAC Zone Case Study
}

\author{
Antoine Ngakosso ${ }^{1}$ \\ ${ }^{1}$ Département de l'Economie Financière, Universite Marien Ngouabi, Congo \\ Correspondence: Antoine Ngakosso, Département de l'Economie Financière, Universite Marien Ngouabi, Congo. \\ E-mail: ndongo_ibara2002@yahoo.fr
}

Received: April 16, 2016

doi:10.5539/ijef.v8n7p244
Accepted: May 23, 2016

Online Published: June 25, 2016

URL: http://dx.doi.org/10.5539/ijef.v8n7p244

\begin{abstract}
This article scrutinizes the relation between the monetary policy and the financial stability driving data from CEMAC zone countries. Furthermore, it aims to know if in addition to its mandate about price stability, the BEAC bank integrates the financial stability in its monetary policy. My method is based on the Taylor Increased Rule estimation of the financial price assets and the econometric test. The results show that the separated policy-mix better fits for CEMAC zone countries. Furthermore, it comes out that the adapted monetary policy practiced by BEAC bank currently ensures the price stability.
\end{abstract}

Keywords: policy-mix, monetary policy, the Taylor increased rule, macro prudential policy, price and financial stability

\section{Introduction}

This paper aims to answer the question whether the financial stability is correlated to the price stability. The financial crisis in 2007 in USA had demonstrated that the financial instability was not the main phenomenon that solely affect emerging economies likely to face economic policy errors or speculative attacks of foreign investors (Cartapanis, 2011). This crisis that the USA financial system, which is viewed as the most reliable, encountered demonstrated that the complex factors leading to a financial instability. It has contributed to the profound revision of most existing financial and bank governance systems with a particular attention to the role of central banks and the relation between monetary and financial stability. In fact, the insight from this financial crisis insistently raises the issue whether, based on the current context of economic globalization, it is not possible to add the financial stability as another objective to the monetary stability within the core responsibility of central banks.

In contrast to monetary stability, which is easily definable and quantifiable, financial stability is a complex concept, hard to grasp and has not yet got a granted definition (Gill Hammond, 2007). It depends on microprudential policy which is concerned on the one hand by the microprudential, which deals with the prevention of individual bank difficulties and on the other hand macroeconomic and monetary stability objectives.

The financial stability can also be accounted by in terms of the financial system instability absence in a whole (Note 1). It is not synonymous to the elimination of the market volatility, but rather by the premonition against an excessive volatility of the asset price on the one hand, and against an excessive expansion of the credit on the other hand.

The financial stability can also become an important factor for the economic growth; the relation between the monetary policy and the financial stability remains a priority either for theoretical or applied research along these decades.

Firstly, on the theoretical ground, the debate on the monetary policy is focused on the relation between inflation and economic activity. The question related to financial stability or instability has been given the second position. In fact, till the crisis, the consensus guiding central bank actions since 1990 was based on the hypothesis that monetary stability was a relevant and sufficient condition for financial stability. Otherwise, the monetary stability necessarily conducted to the financial stability and sustainable economic growth.

This hypothesis was worthy in 1999-2000 known as "Great moderation" period characterized by a low and stable inflation around 2\% amongst G7 countries in contrast to inflationist tensions from 1990 to 2000. Yet, the 
start of the crisis in 2007 has shown that the monetary stability from 1990 to 2000 was prejudicial to financial stability since it has incited economic actors, and particularly banks, to take more risks which lead to the crisis (Borio et al., 2012): it is the credibility paradox. It follows that the mere relation which consisted in claiming that monetary stability is a relevant and sufficient condition to financial stability does not hold. The inflation is not a good indicator to predict a financial crisis (Note 2) and the financial stability becomes a relevant condition to economic growth (Note 3). In this connection, the macroprudential tool looks like an instrument dedicated to fight financial instability, hence the relation between the financial stability and monetary stability gets its climax position either in theoretical or applied research.

Two approaches current raise the debate on the orientation policy clean vs lean monetary policy in front of macroprudential policy: separated policy mix and integrated policy mixed.

The former advocates the separation between monetary policy and macro-prudential policy, each being under the supervision of specific and distinct bodies, one of which is in charge of monetary stability and the other in charge of financial stability (Svensson, 2012, Bernanke, 2010, 2012). According to Tinbergen's rule and Mundell Principle, the separated policy mix asserts that monetary policy depends totally on monetary stability and macroprudential policy on financial stability. The central bank is more implied in the supervision of financial establishments.

The latter approach postulates an integration of the monetary policy and macroprudential policy. One or the other should be ruled by the same body for a better organization between respective objectives (Adrian \& Shin, 2009; Mishkin, 2011; Eichengreen et al., 2011). The monetary and financial stability will be integrated in the same Augmented Taylor Rule. It is about the extension of Taylor Rule in order to include a financial variable such as the credit (Christiano et al, 2010), monetary supply (Issing, 2011) or financial imperfection indicators (Wooford \& Curdia, 2009) (Note 4). However, this approach shows some limitations in connection to the implementation of the rule elaborated by Tinbergen in 1952. Thus, the interest rate cannot alone achieve three objectives: monetary stability, macroconjectural stability, and financial stability.

Intermediary solutions between the two approaches are possible (Note 5). In the light of Beau et al. (2011), the optimal policy mix solely depends on the type of shock, the crossing conditions regarding inflation and financial stability. So, for some central bankers, the integrated system represents an emergency solution, but should only be used if it is "the only possible solution" in case of extreme crisis. Under these exceptional conditions, Bernanke (2012) does not exclude to resort to the interest rate to fight financial instability. Yet, uncoupled policy mix suits under normal circumstances. The choice of policy mix is not simply a theoretical issue, it is rather empirical because it varies according to macroeconomic conditions.

In fact, under empirical view, the general dynamic equilibrium models and stochastic are the main macro conjectural modeling tools issued from macroeconomic theory since the beginning of 2000s. They start integrating financial frictions that they ever integrated before the crisis. The most current integrate the action of macroprudential policy in addition to that of monetary policy.

A number of authors even go further in combining one or more macroprudential tools with one Augmented Taylor Rule for a given financial target, and hence permitting the articulation of the interest rate and the macroprudential tools to restore financial stability.

Moreover, under methodological perspective, the diversity of model is important. Some models standardize reply coefficients of Taylor Rule when the others optimize them. Even when the reply coefficients of Taylor Rule result from optimization, methods are different. The optimization can concern inflation change and production. Or one can have recourse to one function of ad hoc loss of the central bank with or without financial stability as a support argument.

It is thus difficult based on the results of the previous conclusions to hypothesize whether the central banks should take or should not take into account macroprudential policy for their rate regulation. As things stand, it is obvious that a policy that enables to face the accumulation of financial disequilibria is not appropriate and it is not enough that monetary policy responsible try to eradicate macroeconomic consequences during bear phase.

The question that immediately crops out is to know if in the future the monetary policy will more contribute to maintain the financial stability and eventually gets an important role.

So, this is the proven interest of carrying out a study dealing with the relation between monetary policy and financial stability. Furthermore, if we take for granted the hypothesis which is widespread in the literature that macroprudential policy is an essential condition for financial stability, it is worth examining how such a concern is observed in CEMAC (Note 6) zone in view of the importance of the direct and indirect channels through 
which the asset prices affect the economic agent behaviours and the whole economy.

In fact, in CEMAC zone countries, a distinct bank commission shares the bank regulation with BEAC bank, but the global prudential responsibility depends on CEMAC zone council of Ministers. However, other regional entities are in charge of the regulation of non-bank financial establishments of the zone.

Since the macroprudential responsibility is shared, the question raises is whether in addition to its role for financial stability, BEAC bank integrates financial stability in its governance of monetary stability.

The remaining work includes two sections and a concluding remark. Second 2 is about the determination of the model of reaction function of the central bank; the estimation and the analysis of the key results is the concern of section 3 .

\section{Determination Model for BEAC Reaction Function}

This section is devoted to provide an overview of the theoretical framework worthy for the analysis before providing specificity of the model for estimation purpose.

\subsection{Presentation of the Model}

Starting from the hypothesis that the macroprudential policy should stand as an essential tool in the future for the financial stability in CEMAC zone, we purport to provide a method capable of modelling a reaction function for monetary authorities that can include one or more types of macroprudential policies.

Considering, under this perspective Angeloni and Faia (2013), Kannan et al. (2012) and IMF (2012, 2013), a general dynamic equilibrium model and stochastic, which is, as stated so far, the main tool of macroprudential modelling issued from macroeconomic theory.

The advantage of this model is that it enables to incorporate macroprudential rules used to limit financial fluctuations and to represent monetary policy by means of a Taylor Rule which can make reply the interest rate either to fluctuation gaps, production gap and financial gap.

This model is also advantageous as it represents several types of mix policies: separated mix policy according to which monetary policy does not correspond to financial conditions and it centers on the stability of inflation and production, and integrated policy mix which admits that monetary policy cooperate with macroprudential policy and backs it up to respond to financial instability.

The response coefficient value to financial condition under the Taylor Rule that this model uses seems to be the variable that better represents the point of articulation between monetary policy and macroprudential policy in the search for financial stability.

It is then fortunate to explain the differences of the coefficient value and policy mix nature indeed. The function of reaction looks like an Augmented Taylor Rule whose loss function is given the following schema:

$$
E=E_{t}\left(y_{t}-y^{*}-\mu_{t}\right)^{2}+\alpha\left(\pi_{t}-\pi^{*}\right)^{2}+\beta\left(\rho_{t}-\rho^{*}\right)^{2}
$$

Where in:

- $\quad E_{t}$, the expectancy at time $t$ of the loss;

- $\quad \mathrm{y}_{\mathrm{t}}$, refers to effective growth rate at time $\mathrm{t}(\mathrm{y} *$ is the potential production rate);

- $\quad \pi \mathrm{t}$, stands for the inflation rate at time $\mathrm{t}$ (is the token target value by the central banker);

- $\quad p t$, is the financial stability level at time $t$ and $p^{*}$ its optimal level;

- $\quad \mu t$, the different type of shocks that affect an economic activity.

The equation (1) formalizes the response of the nominal interest rate of the central bank with three gaps: an inflation gap, a production gap and a financial gap.

\subsection{Specification of the Model}

It is worth claiming that a financial gap is very complex as it can refer to credit spread, the price of real estate, the price of actions, credit growth rate, or money supply (we can also find synthetic financial indicators).

The inflation, production and financial gap response coefficients are $\beta, \gamma, \delta$ respectively. These coefficients show the intensity of the central bank response and are on top of economy structure (for example inflation/production arbitration) and the central bank preferences represented in its loss function. In this perspective, more the response to the interest rate to financial condition is higher, more the policy mix becomes integrated; conversely when the response is low so the policy mix is separated. The monetary rule specific to this type is as follows: 


$$
i_{t}=\alpha_{0}+\beta X_{t}+\gamma\left(\pi_{t}-\pi^{*}\right)_{t}+\delta\left(\rho_{t}-\rho^{*}\right)_{t}+\mu_{t}
$$

Where in:

- $i_{t}$ is the central interest rate dictated by monetary authorities at time $t$;

- $\mathrm{X}_{\mathrm{t}}$ refers to output gap or production gap at time $\mathrm{t}$;

- $\left(\pi_{\mathrm{t}}-\pi^{*}\right)$ refers to a gap at time $\mathrm{t}$ between the inflation rate and the target established by monetary authorities;

- $\left(\rho_{t}-\rho^{*}\right)_{t}$ represents a gap at time $\mathrm{t}$ between financial value $(\mathrm{pt})$ and their value being fundamental $\left(\mathrm{p}^{*}\right)$;

- $\mu_{t}$ represents error term.

This specification is advantageous as mentioned above because it permits to:

1/- draw a conclusion from policy mix modalities between monetary policy and macroprudential policy;

2/- distinguish between two cases of polarity: a separated policy mix wherein monetary policy remains concentrated on the financial stability and macro-conjectural policy whereas macro prudential policy aims to financial stability in adjusting the central rate concerning financial conditions.

Moreover, we put forward the hypothesis that BEAC is incapable of distinguishing movements in accordance with fundamentals to those which are not.

Following Wooford (2012), one can admit that there is arbitration of BEAC monetary authorities between macroeconomic stability (inflation, production) and financial stability. The response coefficients will depend on BEAC preferences in its loss function. For IFM (2013), it is a commonly argued that for a central bank to think of financial stability affects its anti-inflationist credibility. Three types of constraints are distinguished indeed:

$1-\gamma$ must be negative, we expect a negative relation between $\gamma$ and $\delta$, hence a separate policy-mix due to the objective conflict prejudicial to the central bank credibility in relation to the price stability. Formally, we expect a negative sign for the explanatory variable $\gamma$.

2- The expected sign for $\beta$ variable, i.e. the production, is less obvious. Due to the objective conflict, we can expect a negative sign. Yet, if the central bank is more 'Dove' (high preference for the production and employment and the financial stability by extension) than 'falcon' (strong anti-inflationist preference), he will likely care about the production and look more open to other objectives than inflation. In this perspective, he can also be open to financial objective as a final objective. The expected sign in front of $\beta$ is ambiguous.

3- The financial gap response coefficient value $(\delta)$ is representative to the articulation between monetary policy and macroprudential policy. If the coefficient value is significant, the monetary policy cares about the financial stability. The policy-mix is thus integrated. However, if the coefficient value is not significant, BEAC bank cares less about the financial stability. In this respect, the macroprudential policy is affected by the financial stability objective. The ensuing section is devoted to the estimation of the model as well as its analysis.

\section{Estimation of the Model and Analysis of the Main Results}

We are firstly going to estimate the model through equation 2 before undertaking the analysis of the main major results.

\subsection{The Model Estimation}

The model estimation requires a prior choice of the different variables of the model. This mainly concerns the choice of the interest rate measure, inflation rate, and financial and production gap. In fact, this study drives data from BEAC database. These are annual database and cover 1980-2013 (Note 7) period.

\section{a) The analysis of the model variable}

Firstly, the interest rate is nothing but the central bank refinancing rate for an annual change period. Figure 1 below illustrates the evolution of this variable through time. 
The evolution of interest rate from 1980 to 2013 (\%)

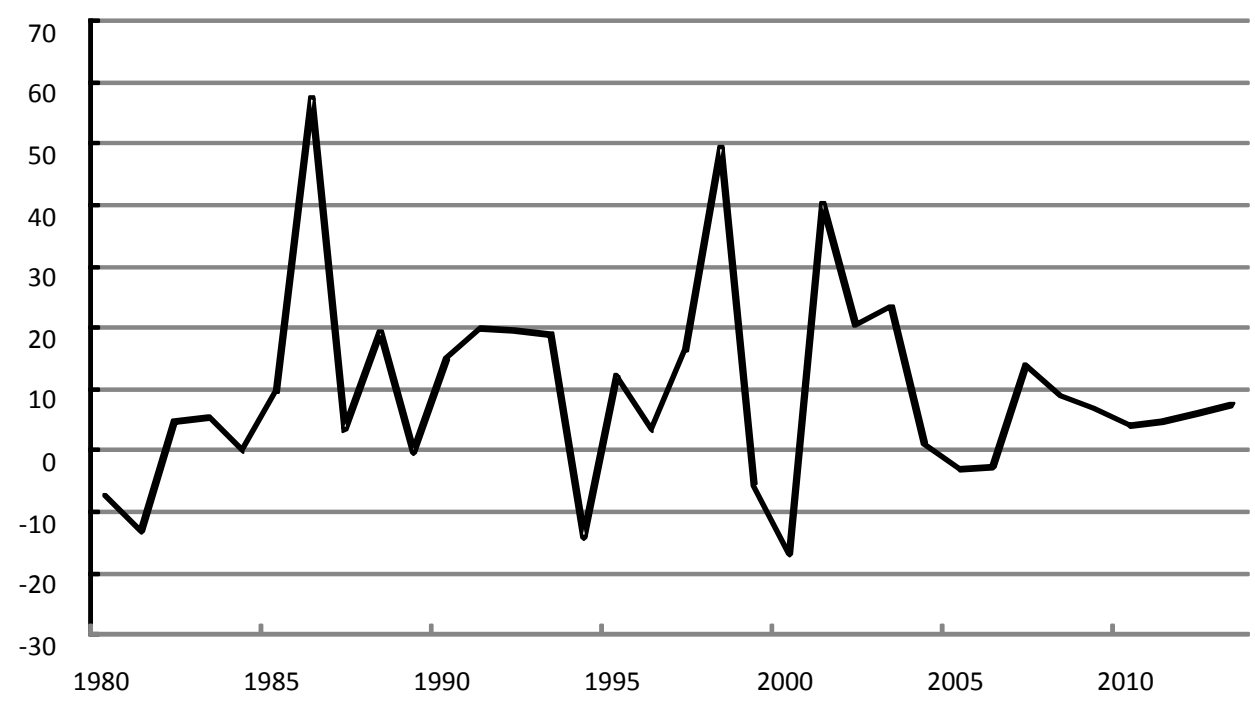

Figure 1. The evolution of interest rate from 1980 to 2013 (\%)

Secondly, the inflation rate is the consumer price index growth rate (IPC) during a year provided by BEAC. Figure 2 shows this variable.

\section{The evolution of inflation rate from 1980 to 2013}

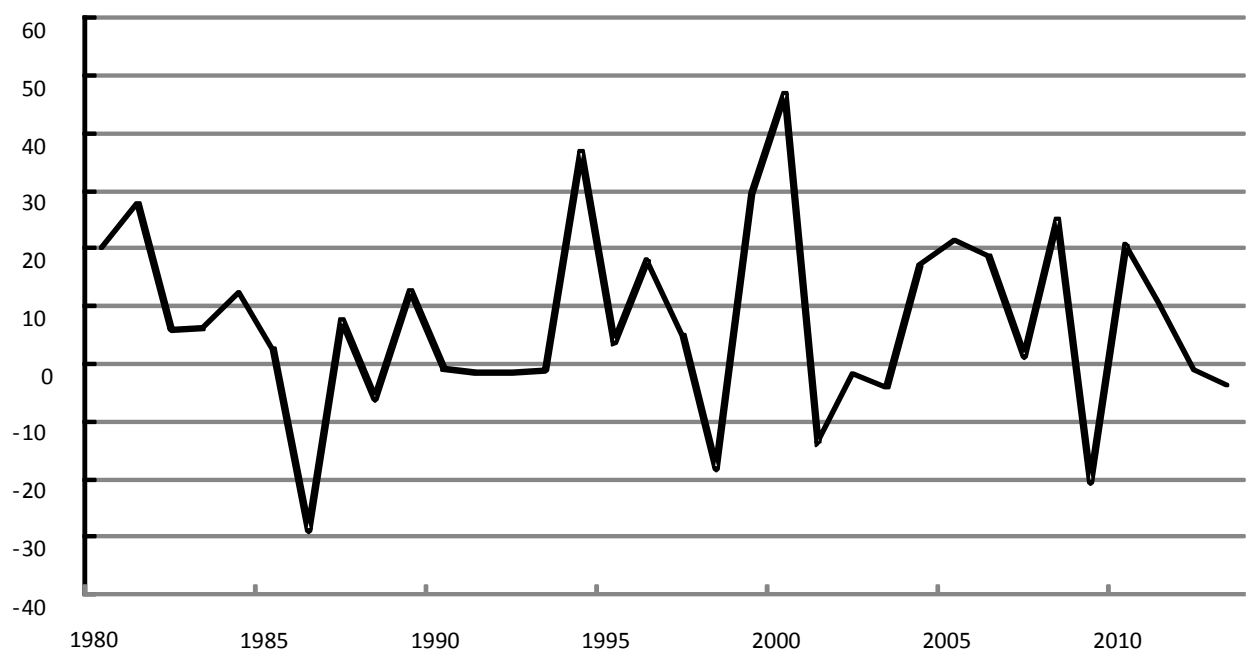

Figure 2. The evolution of inflation rate from 1980 to 2013 (\%)

Thirdly, the output gap measure, the effective rate marked $\mathrm{y}_{\mathrm{t}}$ represents a growth computed from volume index of a real GDP taken from BEAC statistics. We have specifically used In (GDP $\left./ \mathrm{GDP}^{*}\right)$ whereof GDP* is a potential GDP. Potential GDP data have been elaborated following Hodrick-Prescott filter application (Note 8). This approach is worth considering because it provides a statistic estimation framework compatible with a central bank real time analysis. Chart 3 hereafter provide a synthetic overview of this variable for 1980-2013 period. 


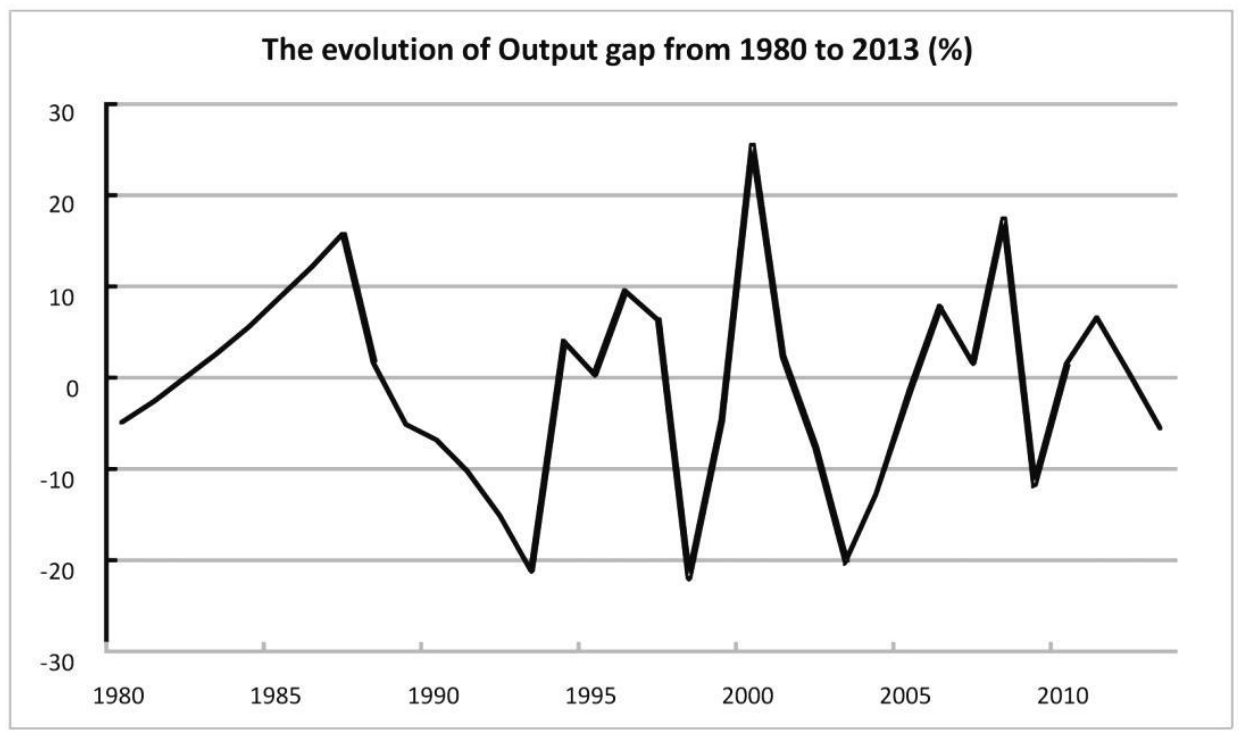

Figure 3. The evolution of output gap from 1980 to $2013(\%)$

Finally, to get macroprudential value, we hypothesize that in CEMAC zone, financial assets are essentially made of cash. Money is a financial asset whose holding depends on its price in connection to other assets. A rise of the interest rate can lead agents to orientate their cash towards a non-monetary investment which is more profitable.

Based on thee bank system and the underdevelopment of money markets, we have selected "proxy" as our value for financial stability, money supply (M2). Statistic data taken as fundamental for this financial variable have been formulated based on Hodrick-Prescott filter. It can be determined as an evaluation error on the financial market index in relation to theoretical price, that is to say, according to the difference between its effective value and potential value established in percentage of the potential value or by logarithmic version In $\left(\mathrm{pt} / \mathrm{p}^{*}\right)$ used afterward.

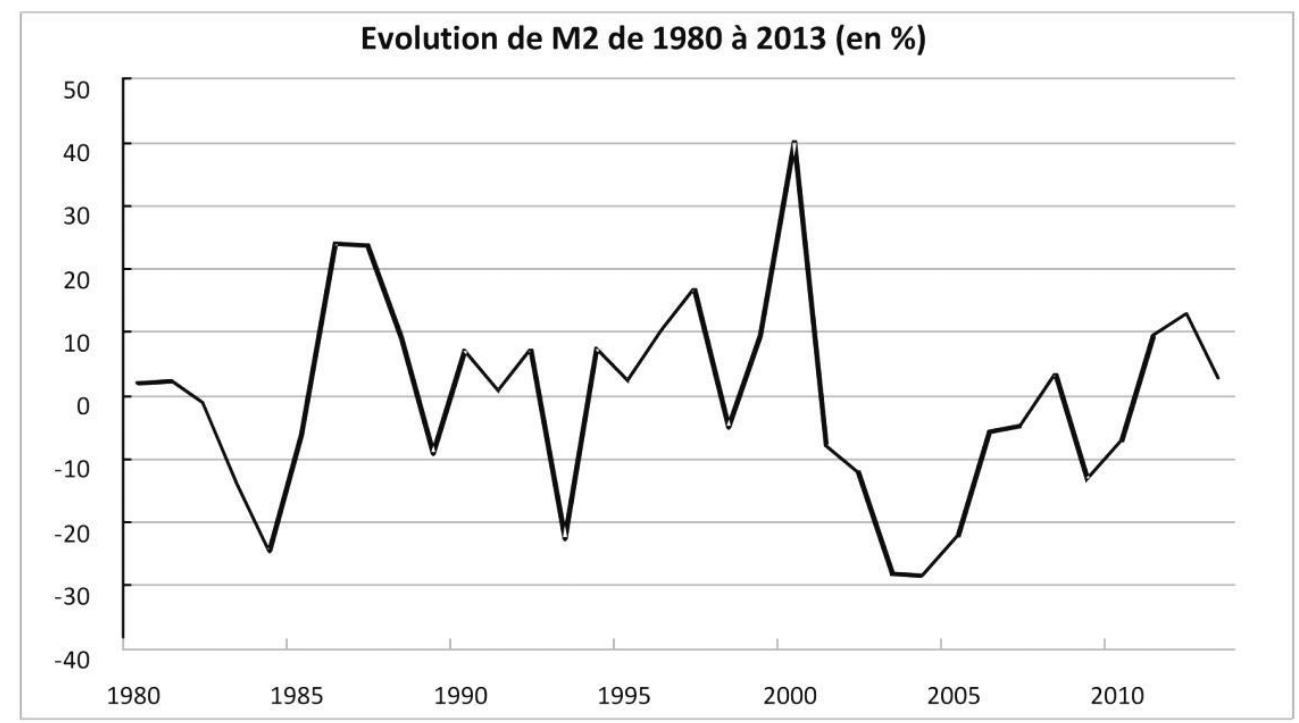

Figure 4. Evolution de M2 de 1980 à 2013 (en \%)

\section{b) Estimated model}

We have firstly proceeded by Dickey-Fuller Augmented test (ADF) in order to test the existence of a unit root, that is, the average of non-stationary tested variables and determine their hierarchy in analysis. Table 1 below points out the major results. 
Table 1. Dickey-Fuller Augment test results

\begin{tabular}{clcccc}
\hline Series & Specification & Delay(s) & Statistics & Critical values & Conclusion \\
\hline$i_{t}$ & with C, no T & 1 & $-5,04$ & $-3,65$ & $\mathrm{I}(0)$ \\
$X_{t}$ & no C, nor T & 1 & $-4,13$ & $-2,64$ & $\mathrm{I}(0)$ \\
$\pi_{t^{-}} \pi_{*}$ & with C, no T & 1 & $-4,90$ & $-3,65$ & $\mathrm{I}(0)$ \\
$\rho_{t^{-}} \rho *$ & no C, nor T & 1 & $-3,51$ & $-2,64$ & $\mathrm{I}(0)$ \\
\hline
\end{tabular}

It transpires from the test that the estimated values of Dickey-Fuller Augmented (ADF) statistics are generally low to the critical values at significance level $1 \%$. Consequently, we reject the null unit root hypothesis in favour of alternative variable stationarity hypothesis. It comes out that all variables are stationary. It is thus pointless to characterize one or more cointegration relation. Let's look at identification strategy in the upcoming lines.

Owing to the intermingled link between the interest rate and macroeconomic variables taken as explanatory variables, we could possibly be in front of reverse causality, and hence endogeneity bias. In order to scrutinize this potential problem, we make use of Granger causality test, the results of which are formulated in Table 2 below.

Table 2. Granger test results

\begin{tabular}{lcc}
\hline \multicolumn{1}{c}{ Tested hypotheses } & F-statistics (p-value) & Conclusion \\
\hline Interest rate does not determine output-gap & $0,07(0,93)$ & Acceptation \\
Interest rate does not determine inflation & $0,34(0,72)$ & Acceptation \\
Interest rate does not determine money supply & $0,39(0,68)$ & Acceptation \\
\hline
\end{tabular}

The results issued from Granger Test come to the conclusion that the three hypotheses are well accepted. Indeed, there is probably no reverse causality in the model, and hence no endogeneity bias. The upcoming section highlights the major results of the estimation.

\subsection{Major Results of the Estimation}

Based on Eviews 7 software, the results of estimation (cf. annexes) appear as follows (Note 9):

$$
\begin{array}{r}
i_{t}=15,90+2,08 X_{t}-0,87\left(\pi_{t}-\pi_{t}^{*}\right)+9,61\left(\rho_{t}-\rho_{t}^{*}\right) \\
(6,95) \quad(0,10) \quad(6,37) \quad(0,94)
\end{array}
$$

$\mathrm{N}=34$;

$\mathrm{R}^{2}$ adjusted: 0,71 ;

Heteroskedasticity correction: White;

$\% \mathrm{Q}=100$

$\mathrm{JB}(\mathrm{p}$-value $)=0,12$.

Under econometric diagnostic level, results are robust to heteroskedasticity by White method application. \%Q indicator proves that there is no fraction auto-correlation, and thence to no delay. Finally, Jarque-Bera test confirms a normal fraction.

Generally speaking, the processed tests on the model promote the validation of the model to represent the interest rate dynamics. In broad sense, two hypotheses can be formulated:

1) Separated policy mix practice in CEMAC zone;

2) An adapted monetary policy rule practice.

\subsubsection{Separated Policy Mix Practice}

It appears that the coefficient associated to asset price variability is low, that is, non-significant. This means that the selected macroprudential tool (money supply) directly constrains borrowers and further reduces the response of monetary policy to financial stability. It is thus less in favour of integrated policy mix wherein monetary policy responds to financial instability in order to support macroprudential policy for financial stability.

It follows that financial stability is not an intermediary objective to BEAC as Figure 5 below illustrated. 


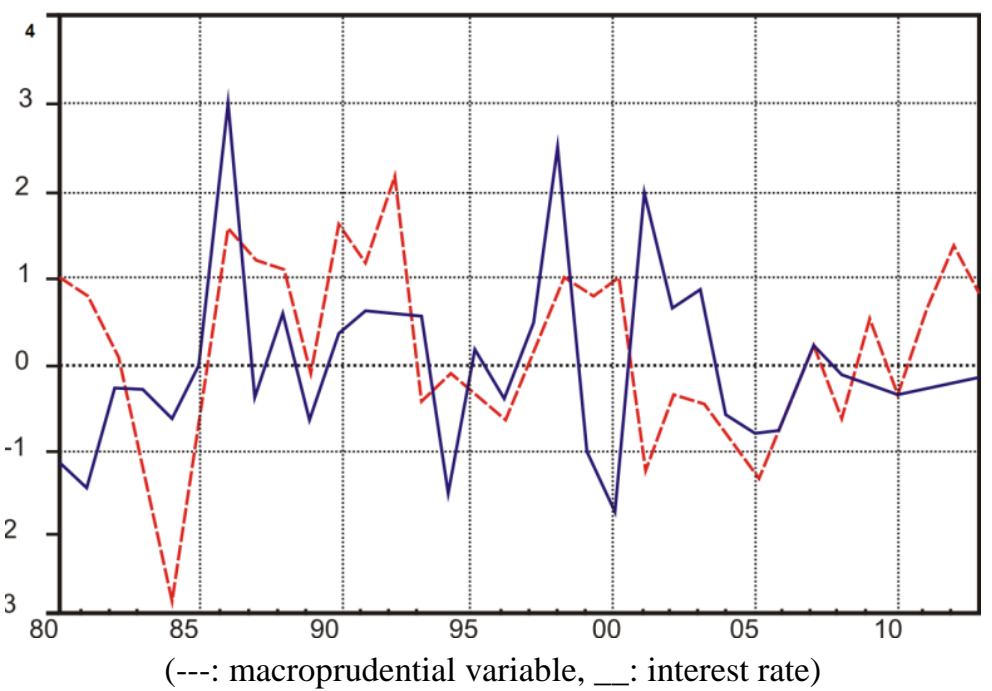

Figure 5. The evolution of the central rate and financial asset prices

It results from Figure 5 that BEAC does not take into account financial asset price because the two series (interest rate and asset price) are not procyclical. This clearly demonstrates that monetary authorities of CEMAC zone are less likely to change their strategy to incorporate a new financial stability objective. Thus, it is doubtless that they will prefer to keep their traditional consensus of separated policy mix instead of integrated policy mix. This confirms the principle that the central rate is independent of the evolution of financial asset price. Since the symbol $\gamma$ is negative, taking into account a new financial stability objective leads to a conflict of objectives which is prejudicial to the credibility of BEAC bank in terms of price stability. As BEAC grants great interest on inflation and engages its credibility in order to achieve its price stability, more it is reluctant to pay attention to financial stability. In this respect, the financial stability must be under macroprudential policy. This leads to the adoption of the separated policy mix in CEMAC zone.

The Implementation of the separate policy mix requires the BEAC bank to adopt an efficient supervision system. This will imply BEAC bank to extend its supervision on banks as well as other intermediary financial establishments, i.e. non-bank financial establishments.

\subsubsection{An Adapted Monetary Policy Rule Practice}

Like the standard Taylor Rule, the monetary policy is optimal if it minimizes the inflation and production gaps. As the coefficient $\gamma$ is negative, this presupposes that the inflation target in CEMAC zone is above the current inflation. In this respect, the BEAC bank authorities are obliged to maintain the short term base rate interest at a low level in order to bring the current inflation up to its target level.

Moreover, the non-significant output gap response coefficient does not seem to influence policy mix in CEMAC zone. Under these conditions, BEAC bank is more concerned with inflation and is not open to other objectives. Economic test results advocate an adapted monetary policy rule with a unique objective related to goods and service price stability. Put otherwise, as the interest rate is the adjustment variable which allows to stabilize inflation to its low level in the CEMAC zone leads to the implementation of an adapted monetary policy.

By maintaining interest rate to its low level, monetary policy can stimulate demand, but under the current circumstances in CEMAC zone, the efficiency of the decrease of credit rate for consumption stimulation and private investments solely depends on the good working of the channel for bank credit. Marginal advantages of supplementary stimulus are larger when banks are ready to increase credit availability in adjusting credit allocation in accordance with monetary condition loosening when credit procedures are not loosened.

Yet, it is obvious that institutional organizations in CEMAC zone are more and more facing prudential norms which do not prompt them to allocate credits (Engone, 2014).

\section{Conclusion}

This paper has examined the link between the monetary policy and financial stability in CEMAC zone. It has checked if the financial stability management in the CEMAC zone is integrated in the monetary policy governance. In this connection, a BEAC bank reaction function is estimated in integrating not only an inflation 
and a growth gap, but also a financial stability variable.

So it appears that an integrated policy-mix is rejected in CEMAC zone in favor of a separated policy mix. In fact, the macroprudential policy becomes the only suitable instrument to ensure financial stability in CEMAC zone.

Finally, the interest rate being an adjustment variable to stabilize inflation at a low level in CEMAC zone countries leads to the adoption of an adapted monetary policy in view of bringing the current inflation up to the level of the inflation target; what will reinforce the BEAC bank credibility

\section{References}

Agénor, P., \& Pereira Da Silva, L. (2013). Inflation targeting and financial stability: A perspective from the developing world. Banco Central do Brasil. Working Papers $\mathrm{n}^{\circ} 324$.

Alchian, A., \& Klein, B. (1973). On a correct measure of inflation. Journal of Money, Credit and Banking, 5(1), 73-191. http://dx.doi.org/10.2307/1991070

Angeloni, I., \& Faia, E. (2013). Capital regulation and monetary policy with fragile banks. Journal of Monetary Economics, 60(3), 311-324. http://dx.doi.org/10.1016/j.jmoneco.2013.01.003

Bank of England. (2009). The role of macroprudential policy. A discussion Paper.

Bank of England. (2011). Instruments of macroprudential policy. A discussion Paper.

Bean, C., Paustian, M., Penalver, A., \& Taylor, T. (2010). Monetary policy after the fall. Proceedings of Jackson Hole conference, FRB Kansas city, pp. 267-328.

Bean, C. (2011). Central banking then and now. Speech, 12 July.

Beau, D., Clerc, L., \& Mojon, B. (2011). Macro-prudential policy and the conduct of monetary policy, Banque de France. Occasional Papers No. 8, p. 13.

Bernanke, B. (2010). Causes of the recent financial and economic crisis, Statement before the Financial Crisis Inquiry Commission.

Bernanke, B. (2012). The Federal Reserve and the financial crisis. Lecture 2, 22 March.

Bernanke, B., \& Mishkin, F. (1997). Inflation targeting: A new framework for monetary policy. Journal of Economic Perspectives, 11(2), 97-116. http://dx.doi.org/10.1257/jep.11.2.97

Blanchard, O. (2000). Bubbles, Liquidity Traps, and Monetary Policy. Japan's Financial Crisis and its Parallels to the US Experience. In R. Mikitani, \& A. Posen (Eds.), Institute for International Economics Special Report 13 (pp. 185-93). Washington: Peterson Institute for International Economics.

Blanchard, O. (2012). Monetary policy in the wake of the crisis. In O. Blanchard, D. Romer, M. Spence, \& Stiglitz (Eds.), In the Wake of the Crisis (pp. 7-14). Cambridge: MIT Press.

Blanchard, O., Dell'Ariccia, G., \& Mauro, P. (2013). Rethinking Macro Policy 2: Getting Granular. IMF Staff Discussion Note, No. 13/03. http://dx.doi.org/10.5089/9781484363478.006

Bordo, M., \& Landon-Larre, J. (2013). What Explains House Price Booms? History and Empirical Evidence. NBER working Paper $\mathrm{N}^{\circ}$ 19584, October 2013.

Bordo, M., \& Wheelock, D. (1998). Comment on Larry Neal, 'The Bank of England's First Return to Gold and the Stock Market Crash of 1825. Federal Reserve Bank of Saint Louis Review (May/June 1998), 77-82.

Bordo, M., Dueker, M., \& Wheelock, D. (2001). Aggregat price shocks and financial instability: Historical analysis. Federal Reserve Bank of Saint Louis Working paper, 2011, n²000-05B.

Borio, C. (2009). L'approche macroprudentielle appliquée à la régulation et à la surveillance financières. Revue de la Stabilité Financière, (13), 35-46.

Borio, C., \& Lowe, P. (2002). Asset Prices, Financial and Monetary Stability: Exploring the Nexus. BIS Working Paper, $\mathrm{n}^{\circ}$ 114. http://dx.doi.org/10.2139/ssrn.846305

Bourbonnais, R. (2015). Économétrie: Cours et exercices corrigés (9th ed.). Paris, Dunod.

Carré, E., Coupey-Souberyan, J., \& Dehmej, S. (2015). La coordination entre la politique monétaire et politique macroprudentielle: Que disent les modèles DSGE? Revue Economique, 66(3).

Cartpanis, A. (2011). Les crises financières. Les Cahiers Français, N0361, 18-22.

Cecchetti, S., Genberg, H., Lipsky, J., \& Wadhwani, S. (2000). Asset Prices and Central Bank Policy. Geneva Reports on the World Economy, No. 2, International Center for Monetary and Banking Studies et CEPR. 
Christensen, I., \& Meh, C. (2011). Countercyclical loan-to-value ratios and monetary policy. mimeo.Junel.

Christiano, L., Eichenbaum, M., \& Evans, C. (2005). Nominal Rigidities and the Dynamic Effects of a Shock to Monetary Policy. Journal of Political Economy, 113(1), 1-46. http://dx.doi.org/10.1086/426038

Christiano, L., Hut, C. L., Motto, R., \& Rostagno, M. (2010). Monetary Policy and Stock Market Booms. NBER Working Papers 16402.

Cooppey-Soubeyran, J. (2011). Quel rôle pour les banques centrales? Cahiers français $\mathrm{n}^{\circ} 361$, Comprendre des marches financirs, Mars-avril.

Curdia, V., \& Woodford, M. (2010). Credit spreads and monetary policy. Journal of Money, Credit and Banking, 42(SI), 3-35. http://dx.doi.org/10.1111/j.1538-4616.2010.00328.x

De Bandt, O., \& Pfister, C. (2003). Politique monétaire, capital bancaire et liquidité des marchés. Revue d'Economie financière, 73, 2013-226. http://dx.doi.org/10.3406/ecofi.2003.5016

Dickey, D. A., \& Fuller, W. A. (1981). The Likelihood Ratio Statistics For Autoregressive Time Series with a Unit Root. Econometrica, 49(4), 1057-1072. http://dx.doi.org/10.2307/1912517

Dickey, D., \& Fuller, W. (1979). Distribution of the estimators for autoregressive time series with unit root. Journal of the American Statistical Association, 74(366). http://dx.doi.org/10.2307/2286348

Eichengreen, B., El-Erian, M., ... Yongding, Y. (2011). Rethinking Central Banking. Washington: Brookings Institution.

Ekholm, K. (2013). Monetary policy, business cycle stabilisation and macroprudential policy. Speech, Banque de Suède, 13 March.

Engle, R. E., \& Granger, C. W. J. (1987). Co-integration and error-correction: Representation, estimation and testing. Econometrica, 55(2), 251-276. http://dx.doi.org/10.2307/1913236

Filardo, A. (2001). Should Monetary Policy Respond to Asset Price Bubbles? Some Experimental Results. Research working Paper, Federal Reserve Bank of Kansas city. http://dx.doi.org/10.2139/ssrn.285413

Fisher, J., Faraboschi, P., \& Desoli, G. (1996). Custom-Fit Processors: Letting Applications Define Architectures. In Proceedings of the 29th Annual International Symposium on Microarchitecture, pp. 324-335. Paris, France. http://dx.doi.org/10.1109/MICRO.1996.566472

Fisher, P., Mahadeva, L., \& Whitley, J. (1996). The Output Gap and Inflation-Experience at the Bank of England. Basle, January.

Flood, R., \& Isard, P. (1989). Monetary policy strategies. IMF Staff Papers, 36(3), 612-32. http://dx.doi.org/10.2307/3867049

Fonds Monétaire International. (2011). Macroprudential Policy: An Organizing Framework, March 14.

Fonds Monétaire International. (2012). The interaction of monetary and macroprudential-policies- Background Paper, 27 December.

Fonds Monétaire International. (2013a). The interaction of monetary and macroprudential policies, 29 January.

Fonds Monétaire International. (2013b). 'Key aspects of macroprudential policy-background paper, 10 June.

Fuller, W. A. (1976). Introduction to statistical time series. John Wiley quoted in Bourbonnais (2015).

Gali, J. (2013). Monetary policy and rational asset price bubbles. American Economic Review, Forthcoming.

Gill, H. (2007). Définitions et caractéristiques de la stabilité financière pour les pays en Développement. Revue Economique et Monétaire, (1), 5-12.

Goodhart, C. (2001). What weight should be given to asset prices in the measurement of inflation. The Economic Journal, 111, 335-356. http://dx.doi.org/10.1111/1468-0297.00634

Goodhart, C., Osorio, C., \& Tsomocos, D. (2010). The optimal monetary policy instrument, inflation versus asset price targeting, and financial stability. In D. Cobham, O. Eitrheim, \& S. Gerlach (Eds.), Twenty Years of Inflation Targeting (pp. 192-231). Cambridge: Cambridge University Press. http://dx.doi.org/10.1017/CBO9780511779770.010

Hiratsuka, S. (1999). Asset Price Fluctuation and Price Indices. Institute for Monetary and Economic Studies, Discussion Paper, Bank of Japan.

Hodrick, R. J., \& Prescott, E. C. (1997). Postwar U.S. Business Cycles: An Empirical Investigation. Journal of 
Money, Credit, and Banking, 29, 1. http://dx.doi.org/10.2307/2953682

Issing, O. (2011). Lessons for monetary policy: What should the consensus be? IMF.

Jarque, C. M., \& Bera, A. K. (1984). Testing the normality assumption in limited dependant variable models. International Economic Review, 25(3), 563-578. http://dx.doi.org/10.2307/2526219

Jean, L. R., \& Balli, F. (2013). Low-Inflation-Targeting Monetary Policy and Differential Unemployment rate: Is Monetary Policy to Blanred for the financial crisis? Economic Modelling, 30(January 2013), 546-64. http://dx.doi.org/10.1016/j.econmod.2012.09.042

Johansen, S. (1991). Estimation And Hypothesis Testing of Cointegration Vectors in Gaussian Vector Autoregressive Models. Econometrica, 59, 1551-1580. http://dx.doi.org/10.2307/2938278

Kannan, P., Rabanal, P., \& Scott, A. (2012). Monetary and macroprudential policy rules in a model with house price booms. The B.E. Journal of Macroeconomics, 1-42. http://dx.doi.org/10.1515/1935-1690.2268

Ljunge, G. M., \& Box, G. E. P. (1978). On Measure of Lack of Fit in Time Series Models. Biometrika, 65, 297-303. http://dx.doi.org/10.1093/biomet/65.2.297

Mignon, V., \& Lardic, S. (2002). Économétrie des séries temporelles macroéconomiques et financières. Economica.

Mishkin, F. (2011). How should central banks respond to asset-price bubbles? The lean versus clean debate. Banque de Réserve d'Australie, Bulletin, June Quarter, 59-69.

Olsen, O. (2013). Countercyclical capital buffer - criteria for use and interaction with monetary policy. speech, Banque de Norvège, 18 April.

Ozkan, G., \& Unsal, F. (2011). Leaning against the wind, but how? Monetary policy versus macroprudential measures. Working Paper, November 2011.

Praet, P. (2011). Housing cycles and financial stability - The role of the policymaker. Speech, 24 November.

Reinhart, C. M., \& Rogoff, K. S. (2009). This Time is Different. Eight Centuries of Financial Folly. Princeton University Press.

Rogoff, K. (1985). The Optimal Degree of Commitment to an Intermediate Target. Quarterly Journal of Economics, 100(4), 1169-90. http://dx.doi.org/10.2307/1885679

Rotemberg, J., \& Woodford, M. (1998). An optimization-based econometric framework for the evaluation of monetary policy. NBER Macroeconomics Annual 1997, 297-346.

Schwartz, A. (1988). Financial Stability and the Federal Safety Net. In S. W. Haraf, \& R. M. Kushneider (Eds.), Restructuring Banking and Financial Services in America (pp. 34-62). American Enterprise Institute.

Schwartz, A. (1995). Why Financial Stability Depends on Price Stability. Economic Affairs, 21-25. http://dx.doi.org/10.1111/j.1468-0270.1995.tb00493.x

Shibuya, H. (1992). Dynamic equilibrium price index: Asset price and inflation, monetary and economic studies. Institute for Monetary and studies, Bank of Japan, 10(1), 95-109.

Solow, R. (1999). How cautious the Fed must be? In B. Friedman (Ed.), Inflation, Unemployment and Monetary Policy (pp. 1-28). MIT Press.

Stein, J. (2013). Overheating in Credit Markets: Origins, Measurement, and Policy Responses. Speech, February.

Stephen, B., \& Mareva, S. (2007). Économétrie : des fondements à la modélisation. Paris, Edition Vuibert.

Svensson, L. (2012). Comment on Michael Woodford, Inflation Targeting and financial stability. Rikshank Economic Review, 1, 33-9.

Taylor, J. (1993). Discretion versus policy rules in practice. Carnegie-Rochester Conference Series on Public Policy, 39, 195-214. http://dx.doi.org/10.1016/0167-2231(93)90009-L

Tinbergen, J. (1952). On the Theory of Economic Policy. Amsterdam: North Holland.

Tobias, A., \& Hyun, S. S. (2009). Prices and quantities in the monetary policy transmission mechanism. Staff Reports 396, Federal Reserve Bank of New York.

Toloni, R., \& Mcculley, P. (2008). Chasing the Neutral Rate Down; Financial Conditions, Monetary Policy, and the Taylor Rule. PIMCO, Global Central Banks Focus, 2008. 
Turner, D. (1995). Speed Limit and Asymmetric Effects from the Output Gap in the Major Seven Countries. OECD Economic Studies, 24, 58-87.

Woodford, M. (2003). Interest and prices. Princeton: Princeton University Press.

Woodford, M. (2012). Inflation Targeting and financial stability? Sveriges Riksbank Economic Review, 1, 7-32.

\section{Notes}

Note 1. In contrary to microprudential approach which is interested in each firm but individually.

Note 2. So, the financial stability cannot be considered as a secondary objective because the crisis has demonstrated that the search for the price stability was an important condition, but insufficient to guarantee financial stability. Accordingly, the correlation between the two objectives, financial stability and monetary stability becomes an insightful question.

Note 3. The credibility paradox is similar to the tranquility paradox (Hyman Minsky, 1980) according to which the excessive debt crisis is settled down when everything is good because the economic agents take the advantage of the growth and the interest rate to borrow more. Yet, an interest rate turnaround further to a monetary policy tightening renders a sustainable debt unsustainable.

Note 4. The hypothesis appealing to broaden the definition of inflation measure in order to include some asset prices is relevant (Alchian \& Klein, 1973; Shibuya, 1992). Augmented Taylor Rule means that monetary policy is oriented "lean" to defend macroprudential tool; interest rate and macroprudential tools are supposed to have complementary actions.

Note 5. It concerns conditional policy mix or intermediary approach which is formulated in terms of Asymmetric Taylor Rule or non linear sometimes non augmented with a response coefficient on stability changing over time.

Note 6. CEMAC (Economic and Monetary Community of Central Africa) includes six countries: Cameroun, Congo, Gabon, Central African Republic, Equatorial Guinea, and Chad. These countries have a common central bank, Bank of Central African States (BEAC).

Note 7. The choice of the period and sampling period depended on data availability. In fact, infra annual data were unavailable.

Note 8. The filter elaborated by Hodrick and Prescott (HP filter) has been applied in many surveys to evaluate potential production (Fisher et al., 1996, Turner, 1995). We have applied a 100 smoothing parameter, a value which is generally used for annual data.

Note 9. Student statistics appear between brackets. \% Q is an indicator which summarizes the conclusion of Ljung-Box test on fraction autocorrelation to all delays. It particularly provides delays for which the autocorrelation absence hypothesis is approved. For example, if $\% \mathrm{Q}=100$, this stands for $100 \%$ of cases, so the autocorrelation absence hypothesis is approved. The selection of this indicator avoids to choose a specific delay that should conduct to the approval of Ljung-Box test. Moreover, Jarque-Bora p-value test is reported. The tested hypothesis is that fraction distribution is normal. A p-value above 0.05 leads to the approval of the tested hypothesis.

\section{Appendix}

\section{Abbreviations:}

TIR $=$ Interest rate

$\mathrm{X}=$ output-gap

$\mathrm{INF}=$ inflation rate

$\mathrm{P}=\mathrm{M} 2$ potential growth 


\section{Granger Tests:}

Granger Test of interest rate / output-gap

\begin{tabular}{lccc}
\hline Pairwise Granger Causality Tests & & & \\
Date: $09 / 08 / 15 \quad$ Time: $11: 02$ & & & \\
Sample: 134 & & & \\
Lags: 2 & Obs & F-Statistic & Probability \\
\hline Null Hypothesis: & 32 & 3.69200 & 0.03825 \\
X does not Granger Cause TIR & & 0.07020 & 0.93238 \\
\hline
\end{tabular}

Granger Test of interest rate / inflation rate

\begin{tabular}{lccc}
\hline Pairwise Granger Causality Tests & & & \\
Date: $09 / 08 / 15 \quad$ Time: $11: 04$ & & & \\
Sample: 134 & & & \\
Lags: 2 & Obs & F-Statistic & Probability \\
\hline Null Hypothesis: & 32 & 0.15962 & 0.85326 \\
INF does not Granger Cause TIR & & 0.33629 & 0.71737 \\
TIR does not Granger Cause INF & & &
\end{tabular}

Granger Test of interest rate / money supply

\begin{tabular}{lccc}
\hline Pairwise Granger Causality Tests & & & \\
Date: 09/08/15 Time: 11:05 & & & \\
Sample: 134 & Obs & F-Statistic & Probability \\
Lags: 2 & 32 & 2.52026 & 0.09919 \\
\hline Null Hypothesis: & & 0.38772 & 0.68232 \\
P does not Granger Cause TIR & & & \\
TIR does not Granger Cause P2
\end{tabular}

\section{Conclusion:}

Hypothesis A in every table: we reject tested hypothesis for X, we accept that of INF and accept bound to P. This provides an indication for the final estimation: we can expect $\mathrm{X}$ to be significant, $\mathrm{P}$ is slightly significant or slightly non-significant, and INF is non-significant.

Hypothesis B in every table: we accept the tested hypothesis for all cases. This presupposes that there is no reverse causality for none variables. There is no endogeneity to deal with.

\section{Estimations:}

1) No correction with White

\begin{tabular}{|c|c|c|c|c|}
\hline \multicolumn{5}{|l|}{ Dependent Variable: TIR } \\
\hline \multicolumn{5}{|l|}{ Method: Least Squares } \\
\hline Date: 09/08/15 & & & & \\
\hline \multicolumn{5}{|l|}{ Sample: 134} \\
\hline \multicolumn{5}{|c|}{ Included observations: 34} \\
\hline Variabl & Coefficient & Std. Error & t-Statistic & Prob. \\
\hline $\mathrm{C}$ & 15.89905 & 1.690597 & 9.404400 & 0.0000 \\
\hline $\mathrm{X}$ & 2.075009 & 19.18822 & 0.108140 & 0.9146 \\
\hline INF & -0.868615 & 0.102839 & -8.446327 & 0.0000 \\
\hline $\mathrm{P}$ & 9.605676 & 12.51075 & 0.767794 & 0.4486 \\
\hline R-squared & 0.737294 & Mean dependent var & & 9.567059 \\
\hline Adjusted R-squared & 0.711023 & S.D. dependent var & & 16.19935 \\
\hline S.E. of regression & 8.708217 & Akaike info criterion & & 7.276542 \\
\hline Sum squared resid & 2274.992 & Schwarz criterion & & 7.456114 \\
\hline Log likelihood & -119.7012 & F-statistic & & 28.06531 \\
\hline Durbin-Watson stat & 2.014967 & Prob(F-statistic) & & 0.000000 \\
\hline
\end{tabular}


2) With correction by White:

Dependent Variable: TIR

Method: Least Squares

Date: 09/08/15 Time: 12:03

Sample: 134

Included observations: 34

White Heteroskedasticity-Consistent Standard Errors \& Covariance

\begin{tabular}{lrlrc}
\hline \multicolumn{1}{r}{ Variable } & Coefficient & Std. Error & t-Statistic & Prob. \\
\hline C & 15.89905 & 2.287690 & 6.949828 & 0.0000 \\
X & 2.075009 & 20.84045 & 0.099566 & 0.9214 \\
INF & -0.868615 & 0.136272 & -6.374121 & 0.0000 \\
P & 9.605676 & 10.17524 & 0.944024 & 0.3527 \\
\hline R-squared & 0.737294 & Mean dependent var & & 9.567059 \\
Adjusted R-squared & 0.711023 & S.D. dependent var & & 16.19935 \\
S.E. of regression & 8.708217 & Akaike info criterion & \\
Sum squared resid & 2274.992 & Schwarz criterion & & 7.276542 \\
Log likelihood & -119.7012 & F-statistic & 7.456114 \\
Durbin-Watson stat & 2.014967 & Prob(F-statistic) & & 28.06531 \\
\hline
\end{tabular}

$$
\mathrm{Q}=100 \%
$$

$\mathrm{JB}(\mathrm{p}$-value $)=0.12$

The tests prove that there is no need to correct fraction autocorrelation.

The tests show normal fractions, and hence the processing of tools is not relevant.

The correlations between explanatory variables (see below) show an above correlation between $\mathrm{X}$ and $\mathrm{P}$ which could lead to multicollinearity. However, to exclude $\mathrm{P}$ does not change anything to $\mathrm{X}$, and vice-versa.

\begin{tabular}{ccccc}
\hline & INF & $\mathrm{X}$ & $\mathrm{P} 1$ & $\mathrm{P} 2$ \\
\hline $\mathrm{INF}$ & 1.000000 & 0.416804 & -0.197958 & 0.174831 \\
$\mathrm{X}$ & 0.416804 & 1.000000 & -0.102925 & 0.609100 \\
$\mathrm{P}$ & 0.174831 & 0.609100 & 0.664055 & 1.000000 \\
\hline
\end{tabular}

Series are stationary indeed and does not require any processing.

\section{Copyrights}

Copyright for this article is retained by the author(s), with first publication rights granted to the journal.

This is an open-access article distributed under the terms and conditions of the Creative Commons Attribution license (http://creativecommons.org/licenses/by/3.0/). 